\title{
Pengaruh Diabetes Self Management Education and Support (DSME/S) terhadap Diabetes Distress pada Pasien Diabetes Melitus Tipe 2 di RSD dr. Soebandi Jember (The Effect of Diabetes Self Management Education and Support [DSME/S] on Diabetes Distress in Patients with Type 2 Diabetes Mellitus in dr. Soebandi Hospital of Jember)
}

\author{
Novita Nurkamilah, Rondhianto, Nur Widayati \\ Fakultas Keperawatan Universitas Jember \\ JI. Kalimantan No. 37 Kampus Tegal Boto Jember Telp./Fax. (0331) 323450 \\ e-mail: rondhianto@unej.ac.id
}

\begin{abstract}
Diabetes Mellitus (DM) is a chronic disease that requires a continous self-care. A low level of knowledge about self-care can worsen health condition and cause diabetes distress. The continuing stress can cause hyperglycemia that lead to complications of DM. DSME/S is a structured health education that facilitates DM patients in implementing and maintaining their behavior for sustainable self-care. This research aimed to analyze the effect of DSME/S on diabetes distress in patients with type $2 D M$. This research was quasi experimental with non randomized control group pretest posttest design. Thirty respondents in this study were divided into 15 respondents as the intervention group and 15 respondents as the control group by consequtive sampling technique. DSME/S was conducted in 6 sessions: 4 sessions in the hospital and 2 sessions at respondent's house. The data were analyzed by using dependent $t$ test and independent $t$ test with significance level of 0.05. The result of dependent $t$ test revealed a significant difference of diabetes distress between pretest and posttest both in the intervention group $(p=0.001)$ and in the control group $(p=0.046)$. Furthermore, independent $t$ test showed a significant difference between intervention group and control group $(p=0.001)$. The decrease of diabetes distress was higher in the intervention group than control group. This result indicates that there was a significant effect of DSME/S on diabetes distress in patients with type 2 DM. Nurses are expected to apply DSME/S as a discharge planning to reduce diabetes distress in patients with type 2 DM.
\end{abstract}

Keywords: diabetes distress, DSME/S, Diabetes Mellitus 


\begin{abstract}
Abstrak
Diabetes Mellitus (DM) merupakan penyakit kronis yang membutuhkan perawatan diri berkelanjutan. Tingkat pengetahuan yang rendah mengenai perawatan diri dapat memperburuk kondisi kesehatan dan menyebabkan diabetes distress. Stres yang terus berlanjut dapat menyebabkan hiperglikemia yang merupakan penyebab komplikasi DM. DSME/S merupakan pendidikan kesehatan terstruktur yang memfasilitasi pasien DM dalam menerapkan dan mempertahankan perilaku mereka dalam perawatan diri yang berkelanjutan. Penelitian ini bertujuan untuk menganalisis pengaruh DSME/S terhadap diabetes distress pada pasien DM tipe 2. Penelitian ini menggunakan metode quasi experimental dengan desain penelitian pre-test and post-test with control group design. Tiga puluh responden dalam penelitian ini dibagi menjadi 15 responden sebagai kelompok intervensi dan 15 responden sebagai kelompok kontrol dengan teknik consequtive sampling. DSME/S dilakukan dalam 6 sesi: 4 sesi di rumah sakit dan 2 sesi di rumah responden. Data dianalisis dengan menggunakan uji t dependen dan uji $t$ independen dengan taraf signifikansi 0,05 . Hasil uji t dependen menunjukkan perbedaan signifikan diabetes distress antara pretest dan posttest baik pada kelompok intervensi $(p=0,001)$ maupun pada kelompok kontrol $(p=0,046)$. Selanjutnya, uji $t$ independen menunjukkan adanya perbedaan signifikan antara kelompok intervensi dan kelompok kontrol $(p=0,001)$. Penurunan diabetes distress lebih tinggi pada kelompok intervensi dibandingkan kelompok kontrol. Hasil penelitian ini menunjukkan bahwa terdapat pengaruh signifikan DSME/S terhadap penurunan diabetes distress pada pasien DM tipe 2. Perawat diharapkan menerapkan DSME/S sebagai discharge planning untuk meminimalisir diabetes distress pada pasien DM tipe 2.
\end{abstract}

Kata Kunci: Diabetes distress, DSME/S, diabetes mellitus

\section{Pendahuluan}

Diabetes melitus (DM) merupakan suatu kelompok penyakit metabolik dengan karakteristik hiperglikemia yang terjadi karena kelainan sekresi insulin, kerja insulin atau keduanya [1]. DM merupakan penyakit yang kompleks dan kronis yang membutuhkan perawatan medis berkelanjutan dan pendidikan pengelolaan mandiri serta dukungan untuk mencegah terjadinya komplikasi akut dan mengurangi risiko terjadinya komplikasi kronis [2]. Stres terkait diabetes disebut dengan diabetes distress, yaitu kekhawatiran pasien tentang manajemen penyakit, dukungan, beban emosional, dan akses ke perawatan mengenai penyakitnya. Diabetes distress berbeda dari depresi, diabetes distress terjadi karena menderita diabetes dan bukan merupakan distres psikiatri [3].

Penelitian oleh Wiastuti pada 30 sampel pasien DM tipe 2 di wilayah kerja Puskesmas Patrang Jember yang diukur menggunakan kuesioner DDS (Diabetes Distress Scale) didapatkan $20(66,7 \%)$ pasien dalam kategori stres sedang, dan $10(33,3 \%)$ pasien dalam kategori stres ringan [4]. Penelitian oleh Sofiana et al. pada pasien DM tipe 2 di ruang rawat inap RSD Arifin Achmad Pekanbaru diperoleh data dari 30 sampel, 16 pasien $(53,3 \%)$ mengalami stres dalam kategori tinggi, 12 pasien (40\%) mengalami stres dalam kategori rendah, dan 2 pasien $(6,7 \%)$ mengalami stres dalam kategori sedang [5].

Tingkat pengetahuan seseorang dapat mempengaruhi daya tahannya terhadap stres. Semakin tinggi tingkat pengetahuan seseorang, maka semakin tinggi tingkat keberhasilannya melawan stres [6]. Semakin tinggi tingkat stres yang dialami oleh pasien diabetes, maka penyakit diabetes melitus yang diderita akan semakin bertambah buruk [7]. Pasien yang mengalami peningkatan pengetahuan dan motivasi akan mencapai hasil yang optimal dalam pengelolaan DM. Oleh karena itu, edukasi DM diperlukan bagi pasien dan keluarga [8].

Salah satu bentuk edukasi dan dukungan pada pasien DM tipe 2 yaitu Diabetes Self Management Education and Support (DSME/S). DSME/S merupakan pendidikan kesehatan terstruktur dan terarah berbasis dukungan yang memfasilitasi pasien DM dalam melaksanakan dan mempertahankan perilaku yang dibutuhkan untuk pengelolaan diri secara berkelanjutan seperti pengambilan keputusan, perilaku perawatan diri, dan pemecahan masalah untuk meningkatkan status kesehatan pasien [9]. Penelitian ini bertujuan untuk menganalisis pengaruh DSME/S terhadap diabetes distress pada pasien DM tipe 2 di 
Nurkamilah, et al, Pengaruh Diabetes Self Management Education and Support (DSME/S)....

RSD dr. Soebandi Jember.

\section{Metode Penelitian}

Penelitian ini menggunakan metode quasy experiment dengan rancangan pretest-posttest with control group design. Penelitian ini dilakukan di ruang rawat inap Adenium dan Anturium RSD dr.Soebandi Jember pada 2 Mei - 27 Mei 2017dan dilanjutkan di masing-masing rumah responden. Teknik pengambilan sampel adalah consequtive sampling dengan melibatkan 30 responden yang terbagi menjadi 15 responden kelompok perlakuan dan 15 responden kelompok kontrol. Kelompok perlakuan diberikan DSME/S yang dilakukan dalam 6 sesi, yaitu 4 sesi di rumah sakit dan 2 sesi di rumah responden. Sedangkan kelompok kontrol tidak diberikan DSME/S, melakukan aktivitas sesuai prosedur rumah sakit dan kebiasaan sehari-hari di rumah. Instrumen penelitian berupa kuesioner DDS (Diabetes Distress Scale). Analisis data menggunakan analisis deskriptif dan inferensial, analisis inferensial berupa uji parametrik yakni uji $t$ dependen dan uji $t$ independen dengan $\alpha=0,05$. Peneliti menggunakan program SPSS 23.0 untuk proses pengolahan data dan analisis statistik.

\section{Hasil Penelitian}

\section{Karakteristik Responden}

Usia Responden

Tabel 1. Distribusi Usia Resonden

\begin{tabular}{lccc}
\hline \multicolumn{1}{c}{ Variabel } & Mean & SD & Min-Maks \\
\hline $\begin{array}{l}\text { Usia (tahun) } \\
\text { Kelompok }\end{array}$ & 58,73 & 5,982 & $47-65$ \\
$\begin{array}{l}\text { perlakuan }(n=15) \\
\begin{array}{l}\text { Kelompok kontrol } \\
(n=15)\end{array}\end{array}$ & 56,00 & 7,061 & $37-65$ \\
\begin{tabular}{l} 
Total $(n=30)$ \\
\hline
\end{tabular} & 57,36 & 6,521 & $37-65$ \\
\hline
\end{tabular}

\section{Lama Responden Mengalami DM}

Tabel 2. Distribusi Lama Resonden mengalami DM

\begin{tabular}{lccc}
\hline \multicolumn{1}{c}{ Variabel } & Mean & SD & Min-Maks \\
\hline $\begin{array}{l}\text { Lama Mengalami } \\
\text { DM (tahun) }\end{array}$ & & & \\
$\begin{array}{l}\text { Kelompok perlakuan } \\
(n=15)\end{array}$ & 2,93 & 1,710 & $1-7$ \\
$\begin{array}{l}\text { Kelompok kontrol } \\
(n=15)\end{array}$ & 4,67 & 2,582 & $1-10$ \\
Total $(n=30)$ & 3,80 & 2,146 & $1-10$ \\
\hline
\end{tabular}

Jenis kelamin Responden

Tabel 3. Distribusi Jenis Kelamin Responden

\begin{tabular}{|c|c|c|c|c|}
\hline \multirow[t]{2}{*}{ Variabel } & \multicolumn{2}{|c|}{$\begin{array}{l}\text { Kelompok } \\
\text { perlakuan }\end{array}$} & \multicolumn{2}{|c|}{$\begin{array}{c}\text { Kelompok } \\
\text { Kontrol }\end{array}$} \\
\hline & Jumlah & $\%$ & Jumlah & $\%$ \\
\hline $\begin{array}{l}\text { Jenis } \\
\text { Kelamin } \\
\text { Laki-laki } \\
\text { Perempuan }\end{array}$ & $\begin{array}{l}8 \\
7\end{array}$ & $\begin{array}{l}53,3 \\
46,7\end{array}$ & $\begin{array}{c}5 \\
10\end{array}$ & $\begin{array}{l}33,3 \\
66,7\end{array}$ \\
\hline Total & 15 & 100 & 15 & 100 \\
\hline
\end{tabular}

\section{Pendidikan Responden}

Tabel 4. Distribusi Pendidikan Responden

\begin{tabular}{lcccc}
\hline \multirow{2}{*}{ Variabel } & \multicolumn{2}{c}{$\begin{array}{c}\text { Kelompok } \\
\text { perlakuan }\end{array}$} & \multicolumn{2}{c}{$\begin{array}{c}\text { Kelompok } \\
\text { Kontrol }\end{array}$} \\
\cline { 2 - 5 } & Jumlah & $\%$ & Jumlah & $\%$ \\
\hline Pendidikan & 10 & 66,7 & 6 & 40 \\
SD Sederajat & 2 & 13,3 & 1 & 6,7 \\
SMP Sederajat & 2 & 13,3 & 8 & 53,3 \\
SMA Sederajat & 1 & 6,7 & 0 & 0 \\
Perguruan Tinggi & 15 & 100 & 15 & 100 \\
\hline Total & & &
\end{tabular}

Pekerjaan Responden

Tabel 5. Distribusi Pekerjaan Responden

\begin{tabular}{lcccc}
\hline \multirow{2}{*}{ Variabel } & \multicolumn{2}{c}{ Kelompok } & \multicolumn{2}{c}{ Kelompok } \\
& \multicolumn{2}{c}{ perlakuantrol } \\
\cline { 2 - 5 } & Jumlah & $\%$ & \multicolumn{3}{c}{ Jumlah } & $\%$ \\
\hline Pekerjaan & & & & \\
Tidak Bekerja & 5 & 33,3 & 6 & 40,0 \\
PNS & 1 & 6,7 & 0 & 0 \\
Wiraswasta & 6 & 40,0 & 8 & 53,3 \\
Petani & 2 & 13,3 & 0 & 0 \\
Pensiunan & 1 & 6,7 & 1 & 6,7 \\
Lain-lain & 0 & 0 & 0 & 0 \\
\hline Total & 15 & 100 & 15 & 100 \\
\hline
\end{tabular}

Penghasilan Responden

Tabel 6. Distribusi Penghasilan Responden

\begin{tabular}{lcccc}
\hline \multirow{2}{*}{ Variabel } & \multicolumn{2}{c}{$\begin{array}{c}\text { Kelompok } \\
\text { perlakuan }\end{array}$} & \multicolumn{2}{c}{$\begin{array}{c}\text { Kelompok } \\
\text { Kontrol }\end{array}$} \\
\cline { 2 - 5 } & Jumlah & $\%$ & Jumlah & $\%$ \\
\hline $\begin{array}{l}\text { Penghasilan } \\
\text { <UMR }\end{array}$ & 12 & 80 & 12 & 80 \\
>UMR & 3 & 20 & 3 & 20 \\
\hline Total & 15 & 100 & 15 & 100 \\
\hline
\end{tabular}


Diabetes Distress Kelompok Perlakuan

Tabel 7. Perbedaan Nilai Diabetes Distress Sebelum dan Setelah DSME/S

\begin{tabular}{|c|c|c|c|c|c|}
\hline Variabel & Mean & Median & SD & $\begin{array}{l}\text { Min- } \\
\text { Maks }\end{array}$ & $\begin{array}{c}p \\
\text { value }\end{array}$ \\
\hline $\begin{array}{c}\text { Diabetes } \\
\text { distress } \\
\text { Pretest }\end{array}$ & 2,32 & 2,35 & 0,32 & $\begin{array}{l}1,76- \\
2,94\end{array}$ & \\
\hline $\begin{array}{l}\text { Diabetes } \\
\text { distress } \\
\text { Posttest }\end{array}$ & 1,67 & 1,65 & 0,19 & $\begin{array}{l}1,35- \\
2,06\end{array}$ & 0,001 \\
\hline
\end{tabular}

Tabel 8. Perbedaan Kategori Diabetes Distress Sebelum dan Setelah DSME/S

\begin{tabular}{|c|c|c|c|c|}
\hline Kategori & Pretest & $(\%)$ & Posttest & $(\%)$ \\
\hline Distress & & & & \\
\hline $\begin{array}{l}\text { Ringan/ tidak } \\
\text { distress }\end{array}$ & 1 & $6,7 \%$ & 14 & $93,3 \%$ \\
\hline $\begin{array}{l}\text { Distress } \\
\text { Sedang } \\
\end{array}$ & 14 & $93,3 \%$ & 1 & $6,7 \%$ \\
\hline Total & 15 & $100 \%$ & 15 & $100 \%$ \\
\hline
\end{tabular}

Diabetes Distress Kelompok Kontrol

Tabel 9. Perbedaan Nilai Diabetes Distress pretest dan posttest

\begin{tabular}{cccccc}
\hline Variabel & Mean & Median & SD & $\begin{array}{c}\text { Min- } \\
\text { Maks }\end{array}$ & $\begin{array}{c}\boldsymbol{p} \\
\text { value }\end{array}$ \\
\hline $\begin{array}{c}\text { Diabetes } \\
\text { distress }\end{array}$ & 2,27 & 2,35 & 0,22 & $\begin{array}{c}1,70- \\
2,59\end{array}$ & \\
$\begin{array}{c}\text { Pretest } \\
\text { Diabetes }\end{array}$ & & & & & 0,046 \\
$\begin{array}{c}\text { distress } \\
\text { Posttest }\end{array}$ & 2,23 & 2,29 & 0,19 & $\begin{array}{c}1,76- \\
2,47\end{array}$ & \\
\hline
\end{tabular}

Tabel 10. Perbedaan Kategori Diabetes Distress pretest dan posttest

\begin{tabular}{ccccc}
\hline \multicolumn{1}{c}{ Kategori } & Pretest & (\%) & Posttest & (\%) \\
\hline $\begin{array}{c}\text { Distress Ringan/ } \\
\text { tidak distress }\end{array}$ & 1 & $6,7 \%$ & 1 & $6,7 \%$ \\
Distress Sedang & 14 & $93,3 \%$ & 14 & $93,3 \%$ \\
\hline Total & 15 & $100 \%$ & 15 & $100 \%$ \\
\hline
\end{tabular}

Diabetes Distress Setelah DSME/S pada Kelompok Perlakuan dan Kelompok Kontrol

Tabel 11. Perbedaan Diabetes Distress Kelompok Perlakuan dan Kelompok Kontrol Setelah DSME/S

\begin{tabular}{cccc}
\hline Variabel & $\begin{array}{c}\text { Mean } \\
\text { Difference }\end{array}$ & t & $\begin{array}{c}\boldsymbol{p} \\
\text { value }\end{array}$ \\
\hline $\begin{array}{c}\text { Difference } \\
\text { Posttest-Pretest } \\
\begin{array}{c}\text { antara kelompok } \\
\text { perlakuan dan } \\
\text { control }\end{array}\end{array}$ &,- 620 & $-13,147$ & 0,001 \\
\hline
\end{tabular}

\section{Pembahasan \\ Karakteristik Responden}

Rata-rata usia responden pada kelompok perlakuan 58,73 , sedangkan pada kelompok kontrol menunjukkan rata-rata usia 56,00 tahun. Usia tersebut masuk dalam rentang usia lansia. Usia lansia berkaitan dengan terjadinya diabetes karena pada usia lansia fungsi tubuh secara fisiologis akan menurun karena terjadi penurunan sekresi atau resistensi insulin sehingga kemampuan tubuh mengendalikan glukosa darah kurang optimal [10]. Usia lansia biasanya memiliki tingkat stres yang lebih rendah karena lansia telah memiliki rasa kepasrahan sehingga mampu menurunkan stressor yang diterimanya terkait penyakit DM [11].

Rata-rata lama responden mengalami DM yaitu 3,80 tahun dengan standar deviasi 2,146. Lama responden mengalami DM paling singkat yaitu 1 tahun dan paling lama yaitu 10 tahun. Semakin lama seseorang mengalami diabetes, maka semakin besar pula risiko mengalami komplikasi diabetes [12]. Komplikasi makrovaskuler pada klien DM tipe 2 meningkat pada tahun kelima setelah terdiagnosa DM [13]. Durasi diabetes melitus erat kaitannya dengan peningkatan stress, akan tetapi jika orang tersebut mampu mengendalikan dirinya dalam memanajemen penyakitnya, maka tingkat stres terkait diabetes tidak akan tinggi [3]. Seseorang yang menderita diabetes dengan durasi lama akan mampu beradaptasi dengan lingkungan jika mampu mengatur distress emosional dan dapat memberikan suatu perlindungan diri terhadap ansietas dan stres terkait diabetes [14].

Responden dalam penelitian ini lebih banyak perempuan dibandingkan laki-laki. Jumlah responden perempuan sebanyak 17 responden $(56,67 \%)$ dan laki-laki sebanyak 13 responden (43,33\%). DM lebih banyak ditemukan pada perempuan dibandingkan lakilaki. Hal ini disebabkan karena perempuan memiliki LDL atau kolesterol jahat yang lebih tinggi dibandingkan laki-laki. Selain itu, perempuan juga memiliki aktivitas dan gaya hidup yang lebih mengarah pada faktor resiko terjadinya DM [10]. Jenis kelamin berperan terhadap terjadinya stres. Salah satu perbedaan respon antara laki-laki dan perempuan saat menghadapi konflik yaitu otak perempuan yang memiliki kewaspadaan negatif terhadap adanya konflik dan stres. Konflik memicu hormon negatif pada perempuan sehingga memunculkan stres, 
gelisah, dan rasa takut. Sedangkan laki-laki pada umumnya menikmati adanya konflik dan persaingan, bahkan menganggap konflik dapat memberikan dorongan yang positif. Hal tersebut menjelaskan ketika perempuan mendapat tekanan, maka umumnya akan lebih mudah mengalami stres dibandingkan laki-laki [15].

Tingkat pendidikan responden kelompok perlakuan paling banyak adalah SD sederajat yaitu sebanyak 10 responden $(66,7 \%)$, sedangkan pendidikan responden kelompok kontrol paling banyak adalah SMA sederajat yaitu sebanyak 8 responden (53,3\%). Tingkat pendidikan memiliki pengaruh terhadap terjadinya DM tipe 2. Orang dengan pendidikan tinggi memiliki banyak pengetahuan mengenai kesehatan sehingga kesadaran akan pentingnya menjaga kesehatan akan tinggi [16]. Namun, tingkat pendidikan juga berkaitan dengan pekerjaan seseorang. Orang dengan pendidikan tinggi biasanya bekerja di kantoran dengan aktivitas fisik yang sedikit, sedangkan tingkat pendidikan rendah biasanya bekerja buruh atau petani dengan aktivitas fisik yang cukup [16]. Tingkat pendidikan seseorang merupakan salah satu faktor yang mempengaruhi stres. Semakin tinggi tingkat pendidikan seseorang, maka semakin mudah berpikir rasional dan menangkap informasi baru. Kemampuan analisis akan mempermudah individu dalam menguraikan masalah baru [17]. Semakin tinggi tingkat pengetahuan seseorang, maka semakin tinggi tingkat keberhasilannya melawan stres [6].

Responden pada kedua kelompok baik kelompok perlakuan maupun kelompok kontrol lebih banyak bekerja sebagai wiraswasta yaitu 6 responden $(40,0 \%)$ pada kelompok perlakuan dan 8 responden $(53,3 \%)$ pada kelompok kontrol. Jenis pekerjaan seseorang dapat mempengaruhi aktivitas fisik yang merupakan salah satu faktor resiko DM tipe 2. Seseorang yang tidak bekerja cenderung memiliki aktivitas kurang sehingga meningkatkan resiko terjadinya DM tipe 2 . Seseorang yang bekerja di kantoran cenderung memiliki aktivitas fisik kurang, sedangkan seseorang yang bekerja sebagai petani atau buruh cenderung memiliki aktivitas fisik cukup [18]. Jenis pekerjaan seseorang berpengaruh terhadap stres berkaitan dengan penghasilan yang didapat dari pekerjaan tersebut [14].

Penghasilan responden kedua kelompok dilihat dari besar UMR Kabupaten Jember tahun 2017 sama besar yaitu 12 responden (80\%) memiliki penghasilan kurang dari UMR dan 3 responden (20\%) lebih dari UMR. Tingkat penghasilan dan kemakmuran suatu bangsa dapat mempengaruhi tingginya prevalensi diabetes di negara tersebut. Hal tersebut disebabkan karena adanya perubahan gaya hidup yang merupakan salah satu faktor risiko terjadinya diabetes terutama di kota-kota besar [16]. Penghasilan seseorang mempengaruhi seseorang untuk melakukan manajemen perawatan DM. Keterbatasan finansial akan membatasi seseorang untuk mencari informasi, perawatan, dan pengobatan untuk dirinya [14].

\section{Diabetes Distress Sebelum dan Setelah diberikan DSME/S pada Kelompok Perlakuan}

Hasil dalam penelitian ini menunjukkan setelah diberikan DSME/S pada kelompok perlakuan terjadi penurunan yang signifikan rata-rata nilai diabetes distress sebesar sebesar 0,65 yaitu dari 2,32 rata-rata sebelum diberikan DSME/S menjadi 1,67 setelah diberikan DSME/S. Setelah diberikan DSME/S, responden dengan tingkat diabetes distress kategori distress ringan/ tidak distress bertambah dari 1 responden $(6,7 \%)$ menjadi 14 responden (93,3\%). Jumlah responden dengan tingkat diabetes distress kategori distress sedang berkurang dari 14 responden $(93,3 \%)$ menjadi 1 responden $(6,7 \%)$. Hasil tersebut sejalan dengan hasil penelitian oleh Wiastuti (2016) yang menunjukkan terjadi penurunan nilai rata-rata stres sebesar 0,49 pada kelompok perlakuan setelah diberikan DSME/S selama 6 sesi dalam 6 minggu pada pasien DM tipe 2 di wilayah kerja Puskesmas Patrang [4].

Hasil uji statistik menunjukkan $p$ value $=$ $0,001<\alpha(\alpha=0,05)$ yang berarti bahwa ada perbedaan yang signifikan antara nilai diabetes distress pretest dan postest pada responden kelompok perlakuan setelah diberikan DSME/S. Hasil penelitian sejalan dengan penelitian Wiastuti yang mendapatkan hasil perbedaan diabetes distress sebelum dan setelah dilakukan DSME/S $p=0,001 \quad(p<0,05)$ [4].

Pemberian DSME/S pada kelompok perlakuan dapat menjadikan klien belajar bagaimana memecahkan masalahnya terkait DM, sehingga pengetahuan klien terkait manajemen diri pasien DM dapat meningkat. Semakin meningkat pengetahuan klien DM mengenai manajemen diri DM, maka semakin meningkat pula keberhasilannya melawan diabetes distress. Selain mendapatkan pendidikan kesehatan secara terstruktur, 
dalam pemberian DSME/S juga terdapat unsur support yang berupa dukungan oleh keluarga atau orang terdekat klien yang dapat membantu dalam perawatan mandiri klien DM sehingga dapat meminimalisir terjadinya diabetes distress. Pada pemberian DSME/S dalam penelitian ini terdapat satu sesi yang membahas manajemen stres. Hal tersebut dapat menyebabkan penurunan diabetes distress pada klien kelompok perlakuan.

\section{Diabetes Distress pada Pretest dan Posttest pada Kelompok Kontrol}

Hasil penelitian ini menunjukkan terjadi penurunan rata-rata nilai diabetes distress sebesar 0,04 yaitu dari 2,27 saat pretest menjadi 2,23 pada posttest kelompok kontrol. Hasil uji statistik menunjukkan $p$ value $=0,046<\alpha(\alpha=0,05)$ yang berarti bahwa ada perbedaan signifikan antara nilai diabetes distress pretest dan postest pada responden kelompok kontrol. Namun demikian, tidak ada perubahan kategori distress pada pengukuran awal (pretest) dan pengukuran akhir (posttest) pada kelompok kontrol yaitu tetap berada dalam kategori distress sedang.

Kelompok kontrol tidak diberikan DSME/S, melakukan aktivitas sesuai prosedur rumah sakit dan aktivitas sehari-hari seperti biasa dirumah. Penurunan rata-rata nilai diabetes distress dapat dimungkinkan karena beberapa faktor, seperti faktor herediter, konstitusi tubuh, kondisi fisik, neurofisiologik, neurohormonal, dan faktor psikoedukatif yang terdiri dari faktor kepribadian, pengalaman, dan kondisi lingkungan [19].

Kemungkinan penyebab menurunnya ratarata nilai diabetes distress pada kelompok kontrol karena pretest dan posttest dilakukan di tempat yang berbeda. Pretest dilakukan di rumah sakit dan posttest dilakukan di rumah klien. Kondisi lingkungan dalam hal ini sangat berpengaruh. Hal ini sesuai dengan teori bahwa tingkat stres yang dialami pasien DM akan berbeda antara pasien DM yang dirawat di rumah sakit dan tidak. Hal tersebut berkaitan dengan hospitalisasi yang merupakan pengalaman penuh tekanan terutama karena perpisahan dengan lingkungan normal biasanya dimana orang lain berarti, seleksi perilaku koping yang terbatas, dan perubahan status kesehatan [20]. Salah satu dampak sakit yang bisa terjadi pada individu yaitu terjadinya gangguan psikologis. Keadaan sakit pada individu dapat mengakibatkan stres, ketegangan, hingga mengalami kecemasan yang berat apabila psikologisnya tidak disiapkan dengan baik. Proses terganggunya psikologis ini di awali dengan adanya konflik terhadap dirinya seperti kecemasan, ketakutan, dan lain sebagainya. Individu yang sehat dapat melakukan banyak aktivitas secara mandiri, namun ketika terdiagnosa penyakit kronis akan muncul ketakutan dan kecemasan atas eksistensi dan performasinya [21]. Berdasarkan hal tersebut, tidak menutup kemungkinan hasil diabetes distress pada responden kelompok kontrol bisa menurun ketika responden telah diperbolehkan keluar dari rumah sakit dan melakukan aktivitas seperti biasa di rumah karena telah mengalami perbaikan kondisi kesehatan.

Penurunan diabetes distress pada kelompok kontrol juga kemungkinan karena responden mendapatkan pengetahuan dari tenaga kesehatan selama di rumah sakit. Beberapa responden mengatakan selama di rumah sakit mereka mendapatkan pendidikan kesehatan mengenai diet DM dari ahli gizi. Hal ini dapat dilihat dari penurunan rata-rata nilai diabetes distress pada poin "Saya merasa bahwa saya tidak mengatur cukup ketat rencana makan saya yang baik" pada kelompok kontrol dari 3,8 rata-rata saat pretest menjadi 3,67 saat posttest. Hal tersebut sesuai dengan pendapat Khan et al., yang mengatakan bahwa tingkat pengetahuan seseorang dapat mempengaruhi daya tahannya terhadap stres, sehingga semakin tinggi tingkat pengetahuan pasien DM mengenai penyakitnya, maka semakin tinggi tingkat keberhasilannya melawan stres terkait DM [6].

\section{Pengaruh DSME/S terhadap Penurunan Nilai Rata-rata Diabetes Distress \\ Rata-rata penurunan nilai diabetes} distress pada kelompok perlakuan sebesar 0,65 , sedangkan pada kelompok kontrol sebesar 0,04 . Hasil analisa uji statistik pada uji $t$ independent terhadap variabel beda nilai diabetes distress pada kelompok perlakuan dan kelompok kontrol yaitu $p=0,001 \quad(p<0,05)$ yang berarti bahwa terdapat perbedaan signifikan nilai diabetes distress antara kelompok perlakuan dan kelompok kontrol. Hal ini menunjukkan adanya pegaruh pemberian DSME/S terhadap nilai rata-rata diabetes distress. Kesimpulan dari pernyataan tersebut adalah Ha diterima dan membuktikan terdapat pengaruh signifikan pemberiaan DSME/S terhadap diabetes distress pada pasien DM tipe 2 di RSD dr. Soebandi Jember. Hasil penelitian ini sejalan dengan penelitian Wiastuti yang menunjukkan adanya perbedaan signifikan nilai stres antara kelompok 
perlakuan dan kelompok kontrol dengan nilai uji $t$ independent menunjukkan $p=0,001(p<0,05)$ yang juga berarti bahwa terdapat perbedaan signifikan nilai stres antara kelompok perlakuan dan kelompok kontrol [4].

Diabetes distress menjadi beban bagi pasien DM dan keluarganya. Diabetes distress mengacu pada reaksi psikologis negatif mengenai diabetes yang terkait dengan beban emosional dan kekhawatiran atas keadaannya yang harus mengelola penyakit kronis yang, rumit dan menuntut [2]. Stres pada pasien DM dapat memperburuk kondisinya karena stres dapat meningkatkan kadar gula darah [22]. Pada keadaan stres, sistem saraf simpatis akan menstimulasi kelenjar adrenal untuk mengeluarkan hormon epinefrin dan norepineftrin ke aliran darah yang juga menstimulasi sistem saraf dan menghasilkan efek metabolik yang akan meningkatkan kadar glukosa darah dan meningkatkan laju metabolisme. Jika stres tetap menetap, hipotalamus akan menstimulasi pituitari anterior untuk memproduksi ACTH yang akan menstimulasi pituitari anterior untuk memproduksi glikokortikoid, terutama kortisol. Kortisol akan menstimulasi katabolisme protein, melepaskan asam amino, menstimulasi pengambilan asam amino oleh hepar dan konversinya menjadi glukosa (glukoneogenesis). Semakin tinggi tingkat stres yang dialami oleh pasien, maka penyakit DM yang diderita akan semakin bertambah buruk [7].

Edukasi DM diperlukan bagi pasien dan keluarga untuk peningkatan pengetahuan dan motivasi sehingga dapat mencapai hasil yang optimal dalam pengelolaan DM [8]. Salah satu bentuk edukasi untuk pasien DM yaitu DSME/S. DSME/S merupakan dukungan yang memfasilitasi pasien DM dalam melaksanakan dan mempertahankan perilaku yang dibutuhkan untuk pengelolaan diri secara berkelanjutan seperti pengambilan keputusan, perilaku perawatan diri, dan pemecahan masalah untuk meningkatkan status kesehatan pasien [9].

Penelitian ini menunjukkan ada pengaruh pemberian DSME/S terhadap penurunan diabetes distress. Klien yang terfasilitasi pengetahuan dan keterampilan dalam melakukan perawatan mandiri DM melalui pemberian edukasi DSME/S yang merupakan pendidikan kesehatan berbasis dukungan secara terarah dan terstruktur dapat belajar bagaimana memecahkan masalahnya terkait DM, sehingga distress terkait DM dapat diminimalisir. Hal ini sesuai dengan salah satu manfaat DSME/S menurut ADA yaitu dapat meningkatkan koping yang sehat serta mengurangi terjadinya distress terkait diabetes dan depresi.

\section{Simpulan dan Saran}

Simpulan dari penelitian ini yaitu ratarata usia responden dalam penelitian ini yaitu 57,36 tahun dan rata-rata lama mengalami DM yaitu 3,80 tahun, sebagian besar responden berjenis kelamin perempuan, distribusi tingkat pendidikan responden sebagian besar berpendidikan SD sederajat, pekerjaan responden paling banyak yaitu wiraswasta, mayoritas responden memiliki penghasilan kurang dari UMR. Ada pengaruh yang signifikan DSME/S terhadap diabetes distress pada pasien DM tipe 2 di RSD dr. Soebandi Jember dengan $p=0,001<\alpha(\alpha=0,05)$.

Hasil penelitian ini dapat menjadi tambahan referensi pengetahuan terutama perawat di rumah sakit khususnya rawat inap untuk menerapkan DSME/S kepada pasien DM tipe 2 agar dapat menurunkan tingkat diabetes distress. Penelitian ini dapat menjadi acuan untuk penelitian selanjutnya yang dapat melakukan penelitian dalam jumlah sampel yang lebih besar dan meneliti mengenai efektifitas pemberian DSME/S terhadap diabetes distress dengan mengontrol faktorfaktor bias yang dapat mempengaruhi penurunan diabetes distress. Penelitian selanjutnya juga dapat meneliti mengenai perbedaan efektifitas pemberian DSME/S secara individu dan berkelompok terhadap penurunan diabetes distres.

\section{Daftar Pustaka}

[1] Perkumpulan Endokrinologi Indonesia. Konsensus pengelolaan dan pencegahan diabetes melitus tipe 2 di Indonesia 2015. Jakarta: PB Perkeni; 2015.

[2] American Diabetes Association (ADA). Standar of medical care in diabetes2017. Diabetes Care. 2017; 39(1).

[3] Islam MR, Karim MR, Habib SH, Yesmin K. Diabetes distress among type 2 diabetic patients. International Journal of Medicine and Biomedical Research. 2013; 2(12).

[4] Wiastuti SM. Pengaruh Diabetes Self Management Education and Support (DSME/S) terhadap stres pada pasien diabetes melitus tipe 2 di wilayah kerja Puskesmas Patrang Kabupaten Jember. Skripsi. Jember: Universitas Jember; 
2016.

[5] Sofiana LI, Elita V, Utomo W. Hubungan antara stress dengan konsep diri pada penderita diabetes mellitus tipe 2 . Jurnal Ners Indonesia. 2012; 2(2).

[6] Khan TM, Sulaiman SAS, Hasalli MA. The causes of depression? a survey among Malaysians about perception for causes of depression. Asian Journal of Pharmaceutical and Clinical Research. 2008; 2(2).

[7] Semeltzer \& Bare. Brunner \& Suddarth's textbook of medical-surgical nursing. $8^{\text {th }}$ ed; 2005. Terjemahan oleh Kencara HY, Ester M, Hartono A, Asih Y. Buku ajar keperawatan medikal bedah Brunner \& Suddarth. Vol 2. Edisi 8. Jakarta: EGC; 2005.

[8] Ernawati. Penatalaksanaan keperawatan diabetes melitus terpadu. Jakarta: Penerbit Mitra Wacana Media; 2013.

[9] American Diabetes Association (ADA). Diabetes Self-management Education and Support in type 2 diabetes: a joint position statement of the American Diabetes Association, the american association of diabetes educators, and the academy of nutrition and dietetics. Diabetes Care. 2015; 38(1).

[10] Jelantik IMG, Haryati E. Hubungan faktor risiko umur, jenis kelamin, kegemukan dan hipertensi dengan kejadian diabetes mellitus tipe ii di Wilayah Kerja Puskesmas Mataram.Media Bina IImiah. 2014; 8(1).

[11] Wulandari DC. Hubungan antara persepsi terhadap penyakit dengan tingkat stress pada penderita diabetes mellitus tipe ii di RSD dr. Haryoto Lumajang. Jurnal Psikologi. Malang: Program Studi Psikologi Fakultas IImu Sosial dan Politik. Universitas Brawijaya; 2011.

[12] Riyadi S, Sukarmin. Asuhan keperawatan pada pasien dengan gangguan eksokrin dan endokrin pada pankreas. Yogyakarta: Graha IImu; 2008.

[13] Hikmah, DKN. Pengaruh senam diabetes melitus terhadap status kardiovaskuler pasien diabetes melitus tipe 2 di Desa Rambipuji Kecamatan Rambipuji Kabupaten Jember. Skripsi. Jember: Program Studi IImu Kepeawatan Universitas Jember; 2015.

[14] Restada EJ. Hubungan lama menderita dan komplikasi diabetes meitus dengan kualitas hidup pada penderita diabetes melitus di Wilayah Puskesmas Gatak Sukoharjo; 2016.

[15] Nasrani L, Purnawati S. Perbedaan tingkat stres antara laki-laki dan perempuan pada peserta yoga di Kota Denpasar. e-jurnal medika udayana. 2015; 4(15).

[16] Irawan D. Prevalensi dan faktor risiko kejadian diabetes melitus tipe 2 di Daerah Urban Indonesia (analisa data sekunder riskesdas 2007). Tesis. Depok: Fakultas Kesehatan Masyarakat Universitas Indonesia; 2010.

[17] Stuart \& Sundeen. Buku saku keperawatan jiwa. Edisi 5. Jakarta: EGC; 2007.

[18] Fitriyani. Faktor risiko diabetes melitus tipe 2 di Puskesmas Kecamatan Citangkil dan Puskesmas Kecamatan Pulo Merak, Kota Cirebon. Skripsi. Depok: FKM Universitas Indonesia; 2012

[19] Suparyanto. Konsep dasar stress [Internet]; 2011. diakses melalui: https://www.scribd.com/doc/93107717/K ONSEP-DASAR-STRES

[20] Potter \& Perry. Fundamental of nursing: Fundamental keperawatan. Edisi 7. Jakarta: Salemba medika; 2009.

[21] Markam S, Slamet SS. Pengantar psikologi klinis. Jakarta: UI-Press; 2003.

[22] Widodo A. Stress pada penderita diabetes mellitus tipe-2 dalam melaksanakan program diet di klinik penyakit dalam RSUP dr. Kariadi Semarang. 2012; 1(1). 